BACK NUMBERS

The Editor has been sent copies of certain back numbers (not necessarily complete volumes). Anybody who wishes to obtain one or more back issues should kindly write to the Editor at The Group Laboratory, St. Mary Abbots Hospital, Kensington, London, W.8.

\section{CORRECTION}

Dr. Meynell writes: 'In the paper by O'Sullivan, Fitzgerald, Malins, and Meynell (J. clin. Path., 13, 527), under the paragraph entitled "Collection of Specimens", the statement at the end "if this was not possible they were stored at $-20^{\circ} \mathrm{C}$." is wrong and should read "were stored at $+4^{\circ} \mathrm{C}$." In this work no specimen had bej్ stored. All were dealt with immediately after collection. We have since compared counts obtained following if mediate inoculation; those after storing at $+4^{\circ} \mathrm{C}$. ov 8 night and those after storing at $-20^{\circ} \mathrm{C}$. overnight. The first two are practically the same. At $-20^{\circ} \mathrm{C}$. viable couffts are quite strikingly reduced. Although $-20^{\circ} \mathrm{C}$. may be satisfactory for storing bacteria and filtrable viruses-it should not be used for viable counts.'

\title{
Association of Clinical Pathologists Broadsheets
}

The following broadsheets (new series) are published by the Association of Clinical Pathologists. They may be obtained from Dr. R. B. H. Tierney, Pathological Laboratory, Boutport Street, Barnstaple, N. Deven, price 1s. each, except nos. 26 and 27 . The prices include postage but air mail will be charged extra.

1 The Disc Technique for the Rapid Determination of Bacterial Sensitivity to Antibiotics. 1952. R. W. FAIRBROTHER.

2 Determination of Sensitivity of $M$. tuberculosis to Streptomycin. 1952. R. L. Vollum.

3 The Detection of Barbiturates in Blood, Cerebrospinal Fluid, Urine, and Stomach Contents. 1953. L. C. NICKOLLS.

4 The Estimation of Carbon Monoxide in Blood. 1953. D. A. STANLEY.

5 The Identification of Reducing Substances in Urine by Partition Chromatography on Paper. 1953. G. B. MANNING.

6 The Paul-Bunnell Test. 1954. R. H. A. SWAIN.

7 The Papanicolaou Technique for the Detection of Malignant Cells in Sputum. 1955. F. HAMPSON.

8 Mycological Techniques: (1) Collection of Specimens. 1956. R. W. RIDDELL.

9 Mycological Techniques: (2) Cultural Isolation. 1956. R. W. RIDDELL.

10 Techniques for Demonstrating L.E. Cells. 1956. J. V. DACIE and L. S. SACKER.

11 The Identification of Serotypes of Escherichia coli Associated with Infantile Gastro-enteritis. 1956. JOAN TAYLOR.

12 The Determination of Serum Iron and Serum Unsaturated Iron-binding Capacity. 1956. ARTHUR JORDAN.

13 The Estimation of Faecal 'Urobilinogen'. 1957. C. H. GRAY.
14 Preservation of Pathological Museum Speęmens. 1957. L. W. PROGER.

15 Cultural Diagnosis of Whooping-cough. 1959. B. W. LACEY.

16 The Rose-Waaler Test. 1957. C. GREENBURY.

17 The Laboratory Diagnosis of Fibrinogen Deficiency. 1958. R. M. HARDISTY.

18 Investigation of Porphyrin/Porphyria. 1958. C. RIMINGTON.

19 Quantitative Determination of Porphobilinogen and Porphyrins in Urine and Faeces. 1958. C. RIMINGTON.

20 Investigation of Haemolytic Anaemia. 1989. J. G. SELWYN.

21 The Dried Disc Technique for Bactefial Sensitivity Tests. 1959. R. W. FAIRBROTHER and J. C. SHERRIS.

22 Safe Handling of Radioactive Tissues in Laboratory and Post-mortem Room. 1959. R. C. CURRAN.

23 Titration of Antistreptolysin O. 1959. GOODER and R. E. O. WILLIAMS.

24 The Periodic Acid-Schiff Reaction. 196्र 9. A. G. E. PEARSE.

25 The Laboratory Detection of Abnormal Hagemoglobins. 1960 . H. LEHMANN.

26 Daily Fatty Acid Excretion. 1960. A C. FRA (2s.)

27 The Preparation of Bone for Histology. 1960. D. H. COLLINS.
Diagnoștic

(2s.) 